Iğdır Üniversitesi Fen Bilimleri Enstitüsü Dergisi, 11(3): 2062-2068, 2021

Journal of the Institute of Science and Technology, 11(3): 2062-2068, 2021

ISSN: 2146-0574, eISSN: 2536-4618

Gıda Mühendisliği / Food Engineering DOI: $10.21597 /$ jist.906094

Derleme Makalesi / Review Article

Geliş tarihi / Received: 30-03-2021

Kabul tarihi / Accepted: 14-04-2021

To Cite: Binici Hİ, Şat İG, 2021. Melatonin and Melatonin-Rich Foods. Journal of the Institute of Science and Technology, 11(3):2062-2068.

\title{
Melatonin and Melatonin-Rich Foods
}

Halil İbrahim BİNİCi ${ }^{1 *}$, İhsan Güngör ŞAT ${ }^{1}$

\begin{abstract}
Vegetables and fruits are found in the most popular diets. And they are considered as rich sources of vitamins and minerals. Vitamin and mineral deficiency are one of the major causes of various diseases that are common nowadays. Especially vitamins which are known to affect directly on various hormones in our body. Melatonin (N-acetyl-5-methoxytryptamine), one of these hormones, is synthesized in various peripheral organs and tissues, especially the pineal gland and retina. Endogenous melatonin secretion rhythm is regulated by the suprachiasmatic nucleus and maintained with a bright dark cycle. Melatonin hormone is responsible for many activities in the human body. In addition to, especially is found in various foods (milk and milk product, nuts, olive oil, and various fruits). In this review, the recent studies that focused on the biosynthesis and metabolism of melatonin in addition to those investigated food content of melatonin and their effects on physiological and biological human health.
\end{abstract}

Keywords: Melatonin, Melatonin hormone, Vegetables, fruits.

\footnotetext{
${ }^{1}$ Halil İbrahim BİNİCI (Orcid ID: 0000-0003-3301-3994), İhsan Güngör ŞAT (Orcid ID: 0000-0001-9868-0208), Ataturk University, Faculty of Agriculture, Department of Food Engineering, Erzurum, Turkey.

*Corresponding Author: Halil İbrahim BİNiCI, e-mail: ibrahimbinici1325@gmail.com

The abstract of this review was presented the '2nd International Eurasian Conference on Science, Engineering and Technology (EurasianSciEnTech 2020)' conference that held in Antep on 7-9 October 2020.
} 


\section{INTRODUCTION}

$\mathrm{N}$-acetyl-5-methoxytryptamine (Figure 1), also known as the hormone melatonin, is a natural neurotransmitter secreted by the pineal gland. This hormone, which is known to increase secretion in the dark, has important functions in the regeneration of cells, strengthening of the immune system, regulation of sleep rhythm and body temperature, as well as being a powerful antioxidant (Claustrat et al., 2005; Ozçelik et al., 2013; Atasoy, 2019).

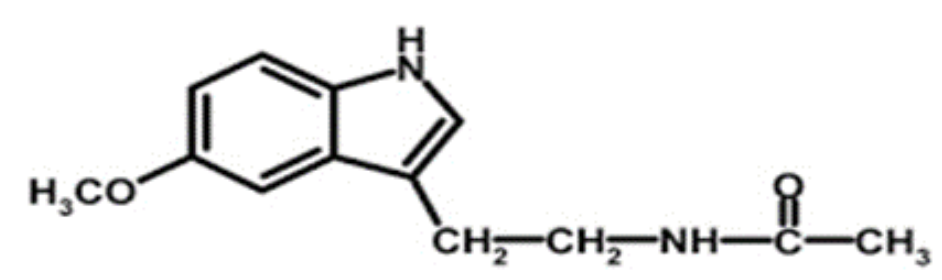

Figure 1. Melatonin (Atasoy, 2019)

The secretion of the melatonin hormone is due to the sensitivity of the pinealocyte cells to light. Thanks to this sensitivity, the obstruction caused by light disappears in the dark and the melatonin secretion of melanocytes increases. Especially between 23:00 and 05:00, melatonin secretion peaks and its concentration in the blood increases 3-10 times. Melatonin release has a special circadian rhythm and begins to increase at 21.00-22.00 hours, reaching a peak at 02.00-04.00 hours. It starts to decrease at 05.00-07.00 in the morning and decreases to basal levels after 07.00. While the blood concentration of melatonin is around 0-20 $\mathrm{pg} \mathrm{dl}^{-1}$ during daytime hours, it increases to 50-200 $\mathrm{pg} \mathrm{dl}^{-1}$ during night hours. An average of $30 \mathrm{mg}$ of melatonin is synthesized during the night (Cam and Erdogan, 2003; Claustrat et al., 2005; Mollaoglu and Ozguner, 2005; Ozcelik et al., 2013).

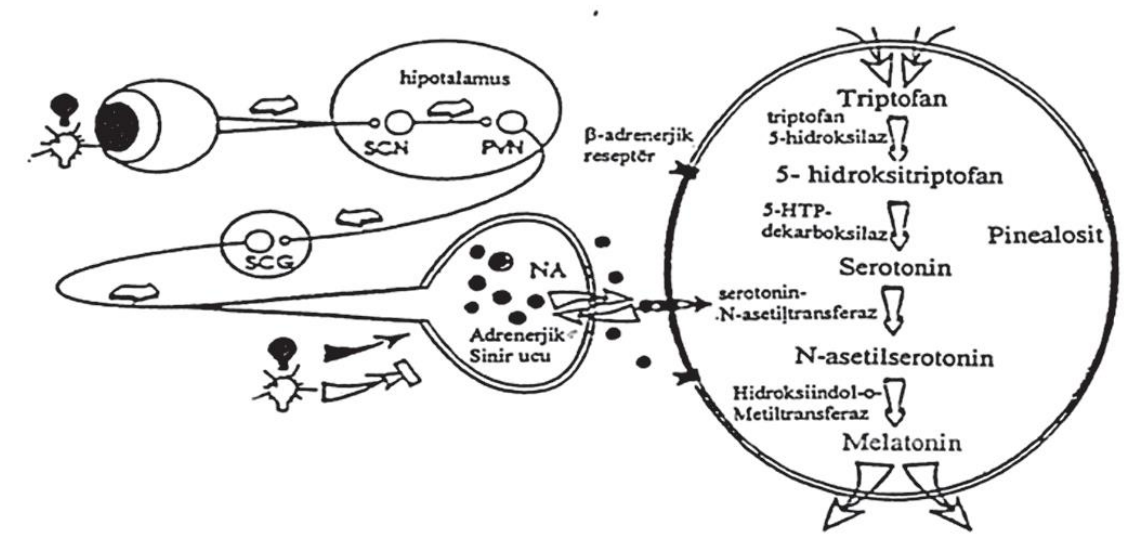

Figure 2. Regulation of melatonin synthesis in dark / light stimulation. (Beyer et al., 1998; Sener, 2010).

As with biochemical, physiological, and behavioural variables, melatonin levels in plasma show regular fluctuations in a 24-hour period. This circadian rhythm is controlled by central pacemakers in the SCN (Suprachiasmatic nucleus) in the hypothalamus, and the main regulator of the rhythm is the light / dark cycle in the external environment (Figure 2). Pineal functions are acutely suppressed when exposed to night light (Liebmann, 1997; Sener, 2010).

The relationship between melatonin and cortisol is important for both hormones in terms of their effects on the immune system. Melatonin and cortisol levels move in the opposite direction. Cortisol is low during sleep hours, whereas melatonin peaks within a few hours after cortisol reaches its lowest level. Interruption of this normal secretion is important in terms of health deterioration or cancer risk. Researchers have reported that various diseases can occur with low melatonin and high cortisol levels. 
So the balance between these two hormones is important for good health. In determining this, the melatonin-cortisol index has been used as a marker in determining the conditions related to depression, heart diseases, osteoporosis and weight gain, in addition to information about immune functions (Millet et al., 1999; Guardiola-Lemaitre, 2007; Sener, 2010). Some findings regarding the relationship between melatonin and cortisol are summarized below:

- Increase in weight gain has been reported to correlate with low melatonin and high cortisol levels (Guardiola-Lemaitre, 2007; Sener, 2010).

- Melatonin levels are lower in patients with depression compared to patients without depression, and cortisol levels were found to be higher in patients with depression during sleep times.

- High cortisol and low melatonin leads to bone loss. Estradiol levels must also be sufficient for melatonin to show its positive effects on the bone.

- Melatonin levels are low in people exposed to light at night and increases the risk of breast cancer. The risk of breast cancer is also associated with cortisol; high cortisol during the day and in the evening increases the risk. Also, it has been reported that melatonin levels are low in the endometrium, prostate, lung, gastric, and colon cancers, and melatonin can be protective against cancer with its antioxidant effects (Reiter et al., 2009; Sener, 2010).

Light applications (or appliances) and effects on Melatonin secretion: While early studies reported that only bright light (daylight) suppresses melatonin level in humans, recent findings suggested that artificial light (lighting system in the dark period) has a similar effect. Melatonin secretion is freely distributed within 24 hours in the visually impaired, ie people with "0" light perception. (Reiter, 1991; Şener, 2010; Reiter, 2002). While the artificial light at night acutely suppresses the synthesis and secretion of melatonin (Figure 4), the light with the onset of dusk shifts the plasma melatonin concentration peak seen between 02.00-04.00 at night, whereas the application of light before sunrise (dawn) in the morning causes this concentration peak to appear early (Figure 4b, c). The light exposure in the morning and evening hours causes a contraction in the phase (Figure 4d) (Claustrat et al., 1998; Şener, 2010).

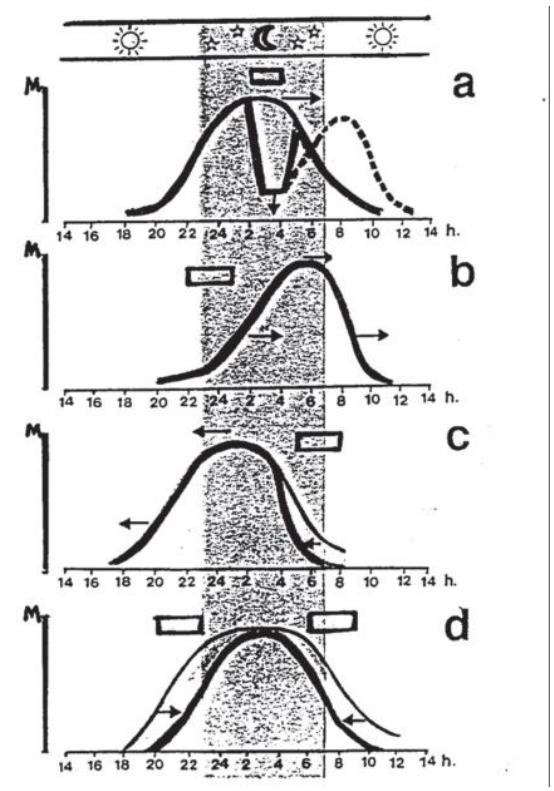

Figure 4. The effects of bright light ( $\square$ ) on melatonin release. a) Inhibition of secretion b) Phase shift.

c) Early phase) Phase contraction (Claustrat et al., 1998; Sener, 2010).

Melatonin has been reported to be more beneficial than other antioxidants in eliminating hypoxia and damage-dependent reoxygenation. Also, it is thought that physiological deficiency of melatonin may 
increase hypoxia and oxidative damage. Therefore, it is thought that the use of melatonin may be important in oxidative damage related to heart diseases (Reiter and Tan, 2003; Ozcelik et al., 2013). It is also reported to be more effective than ascorbic acid in preventing cardiac arrhythmias. (Tan et al., 1998; Ozcelik et al., 2013).

In an in-vivo study, it was found that intravenous melatonin administration prevented ventricular tachycardia, ventricular fibrillation, and premature ventricular contraction (Lee et al., 2002; Ozcelik et al., 2013). Moreover, it is thought that melatonin, which is released during the night, may play an important role in balancing high blood pressure, as it lowers blood pressure and heart rate (Y1ldiz and Akdemir, 2009; Ozcelik et al., 2013).

Melatonin has a direct effect on the bone. It has been found that serum calcium concentration decreases with suppression of melatonin secretion and increases with melatonin administration melatonin administration to ovariectomized rats reduced bone loss (Ostrowska et al., 2002; Şener, 2010). Melatonin is found in abundance in the bone marrow. The effects of melatonin on bone cells is thought to be through autocoid effects. Melatonin also increases bone matrix proteins in a dose-dependent manner. Osteoblastic protein, osteoprotegerin is increased by melatonin (Suzuki et al., 2008; Şener, 2010). It is thought that the use of melatonin, in addition to bisphosphonates in the treatment of osteoporosis, protects bones by both; reducing the side effects associated with the drug and the positive effects directly on the bone.

As a matter of fact, the protective effect of melatonin has been demonstrated against gastric damage caused by alendronate (Sener et al., 2005; Sener, 2010).

\section{Foods Containing Melatonin}

Since, the pinealocyte cells (pineal gland, conarium, or epiphysis cerebri) are sensitive to light, secretion of melatonin occurs in dark environment, not in the light (Paredes et al., 2009; Huang and Mazza, 2011).

In a study that included 24 kinds of edible plants, the amount of melatonin found in edible plants, effects of plasma melatonin rate, and binding efficiency of melatonin receptors in vertebrates have been investigated. At the same time, it has been stated that these plants could be beneficial in terms of nutrition due to the antioxidant properties of melatonin. Melatonin levels of other plants are shown in Table 1.

In another study, melatonin levels in poppy, anise, coriander, celery, flax, green cardamom, clover, fennel, sunflower, almond, goji berry (Lycium barbarum), black and white mustard seeds has been investigated. The amount of melatonin in analyzed samples was found to vary between 2 to $190 \mathrm{ng}$ $\mathrm{g}^{-1}$ with black white mustard having the highest concentration of melatonin (189 $\left.\mathrm{ng} \mathrm{g}^{-1}\right)$ and black mustard (129 $\mathrm{ng} \mathrm{g}^{-1}$ ) (Manchester et al., 2000).

The effect of walnut consumption on the serum melatonin level in the blood of rats has been examined in another study. The study found that the melatonin level in walnuts was $3.5 \pm 1.0 \mathrm{ng} \mathrm{g}^{-1}$ and it was observed that the serum melatonin level of rats fed with walnuts increased compared to those fed with normal diet. Furthermore, the fiber present in walnuts also play an important role in digestive system (Reiter et al., 2005; Binici et al., 2021).

In a study examining the amount of melatonin in extra virgin olive oil, sunflower oil, and refined olive oil, it was observed that the amount of melatonin in extra virgin olive oil samples was higher than in sunflower and refined olive oil samples (de la Puerta et al., 2007). A group of researchers has reported the amount of melatonin that there was no significant difference in melatonin between the samples, but a remarkable difference between the amounts of trans-resveratrol (Mercolini et al., 2008). Stürtz et al. (2011) investigating the melatonin levels found in various tomato (Lycopersicon esculentum) varieties 
(Bond, Borsalina, Catalina, Gordal, Lucinda, Marbone, Myriade, Pitenza, Santonio, Perlino, Platero, and $R A F$ ) and various strawberry (Fragaria ananassa) varieties (Camarosa, Candonga, Festival, and Primoris) in different years (2009-10), the amount of melatonin in tomato samples was found between $4.11 \mathrm{ng} \mathrm{g}^{-1}$ and $114.52 \mathrm{ng} \mathrm{g}^{-1}$, while in strawberry samples it was found between $1.38-11.26 \mathrm{ng} \mathrm{g}^{-1}$. While the amount of melatonin in tomato samples varied according to harvest years, it has been reported that parallel values were obtained in strawberry samples. In other studies investigating the amount of melatonin in various fruits such as grape, banana, orange, pineapple, mango, and papaya, the amount of melatonin in various fruits as reported by the researchers (Mercolini et al., 2012; Johns et al., 2013). In a study by Sang et al. (2020) melatonin contents of fourteen different grains and mulberry leaves had been analyzed. using HPLC- FD. Among the analyzed samples, highest melatonin contents according to the study were: white sesame (75.24), sunflower (67.45), soybeans (56.49), fresh mulberry leaves (51.57). Kocadağlı et al. (2014) study which included the samples of of beer, walnut, tomato, cocoa powder, sour cherry, black and green tea, cherry, cherry concentrate, kefir, breadcrumbs and red wine, melatonin and its isomer were present in beer, hazelnut, tomato and cherry samples, but only melatonin isomer was detected in black and green tea, cherry, cherry concentrate and red wine. It was also reporte that the highest melatonin isomer values were in red wine $\left(170.7 \pm 29.90 \mathrm{ng} \mathrm{g}^{-1}\right)$ and the highest melatonin value was in breadcrumbs $\left(341.7 \pm 29.30 \mathrm{ng} \mathrm{g}^{-1}\right)$ among the analyzed samples.

Table 1. Average amount of melatonin in various plants (Hattori et al., 1995).

\begin{tabular}{|c|c|c|c|}
\hline Plant & Amount (pg g $\left.{ }^{-1}\right)$ & Plant & Amount $\left(\mathrm{pg} \mathrm{g}^{-1}\right)$ \\
\hline Spinach & $38.7 \pm 5.5$ & Strawberry & $12.4 \pm 3.1$ \\
\hline Cucumber & $24.6 \pm 3.5$ & Apple & $47.6 \pm 3.1$ \\
\hline Kiwi & $24.4 \pm 1.7$ & Daisy varities & $416.8 \pm 54.6$ \\
\hline Cabbage & $107.4 \pm 7.3$ & Japanese butterbur & $49.5 \pm 5.6$ \\
\hline Japanese Raddish & $657.2 \pm 29.0$ & Tomato & $32.2 \pm 2.4$ \\
\hline Chinese Cabbage & $112.5 \pm 10.3$ & Rice & $1006.0 \pm 58.5$ \\
\hline Japanese ashitaba & $623.9 \pm 63.1$ & Barley & $378.1 \pm 25.8$ \\
\hline Carrot & $55.3 \pm 11.9$ & Sweet Corn & $1366.1 \pm 465.1$ \\
\hline Oat & $1796.1 \pm 43.3$ & Kentuky blue grass & $5288.1 \pm 368.3$ \\
\hline Taro & $54.6 \pm 23.0$ & Zinger & $583.7 \pm 50.3$ \\
\hline Pineapple & $36.2 \pm 8.4$ & Asparagus & $9.5 \pm 3.2$ \\
\hline Onion & $31.5 \pm 4.8$ & Green Onion & $85.7 \pm 8.0$ \\
\hline
\end{tabular}

\section{CONCLUSION}

Today, the roles of free radicals in various diseases especially cancer, cardiovascular and neurodegenerative diseases, and aging, have been established. And it has brought the use of antioxidants to the agenda and studies on this issue have gradually gained momentum. Compared to many other antioxidants, melatonin continues to be relevant with both its powerful radical scavenging property and its ability to increase antioxidant enzyme activities.

Although there are many studies investigated the melatonin profiles of foods such as various vegetables, fruits, legume seeds, milk and dairy products, coffee and cocoa beans, there are only a limited number of studies examining the melatonin profiles in the human body, especially the effect of consumption of such foods on melatonin profiles in the human body. Moreover, those studies have included oral supplementation of melatonin rather than as a food supplement. From those studies, it is also established that oral supplementation supports the increase of melatonin hormone in the body. But, it is unclear that whether food or external supplements are more effective, due to limited studies, environmental and living conditions, regular sports activities, dietary habits and quality, and factors 
affecting these components. Although, it has been found in many research studies that consuming foods rich in melatonin, regular sports activities, and exposure to sunlight generally increases its concentration in the body, more scientific studies on the effect of melatonin rich diet on human health could provide accurate and systematic results on this subject.

\section{Conflict of Interest}

The article authors declare that there is no conflict of interest between them.

\section{Author's Contributions}

Halil İbrahim Binici wrote the original draft. İhsan Güngör Şat reviewed and edited the manuscript.

\section{REFERENCES}

Atasoy N, 2019. Melatonin ve antioksidan etkileri. Düzce Üniversitesi Sağlık Bilimleri Enstitüsü Dergisi, 9(3): 196-201.

Beyer CE, Steketee JD, Saphier D, 1998. Antioxidant properties of melatonin an emerging mystery. Biochemical Pharmacology, 56 (10): 1265-1272.

Binici, Hİ, Şat, İG, Aoudeh, E, 2021. Nutritional Composition and Health Benefits of Walnut and its Products. Ataturk University Journal of Agricultural Faculty, 52 (2): 224-230.

Cam A, Erdogan MF, 2003. Melatonin. Ankara Üniversitesi Tıp Fakültesi Mecmuası. 56: 103-112.

Claustrat B, Brun J, Chazot G, 2005. The basic physiology and pathophisology of melatonin. Sleep Medicine Reviews, 9(1): 11-24.

Claustrat B, Brun J, Geoffriau M, Chazot G, 1998. Melatonin: from the hormone to the drug? Restorative Neurology and Neuroscience, 12(2, 3): 151-157.

de la Puerta C, Carrascosa-Salmoral MP, García-Luna PP, Lardone PJ, Herrera JL, Fernández-Montesinos R, Pozo D, 2007. Melatonin is a phytochemical in olive oil. Food Chemistry, 104(2): 609-612.

Guardiola-Lemaitre B, 2007. Melatoninergic receptor agonists and antagonists: therapeutic perspectives. Journal de la Societe de Biologie, 201(1): 105-113.

Hattori A, Migitaka H, Iigo M, Itoh M, Yamamoto K, Ohtani-Kaneko R, Reiter RJ, 1995. Identification of melatonin in plants and its effects on plasma melatonin levels and binding to melatonin receptors in vertebrates. Biochemistry and Molecular Biology İnternational, 35(3): 627-634.

Huang X, Mazza G, 2011. Application of LC and LC-MS to the analysis of melatonin and serotonin in edible plants. Critical Reviews in Food Science and Nutrition, 51(4): 269-284.

Johns NP, Johns J, Porasuphatana S, Plaimee P, Sae-Teaw M, 2013. Dietary intake of melatonin from tropical fruit altered urinary excretion of 6-sulfatoxymelatonin in healthy volunteers. Journal of Agricultural and Food Chemistry, 61(4): 913-919.

Kocadağlı T, Y1lmaz C, Gökmen V, 2014. Determination of melatonin and its isomer in foods by liquid chromatography tandem mass spectrometry. Food Chemistry, 153: 151-156.

Lee YM, Chen HR, Hsiao G, Sheu JR, Wang JJ, Yen MH, 2002. Protective effects of melatonin on myocardial ischemia/reperfusion injury in vivo. Journal of Pineal Research, 33(2): 72-80.

Liebmann PM, Wölfler A, Felsner P, Hofer D, Schauenstein K, 1997. Melatonin and the immune system. International Archives of Allergy and İmmunology, 112(3): 203-211.

Manchester LC, Tan DX, Reiter RJ, Park W, Monis K, Qi W, 2000. High levels of melatonin in the seeds of edible plants: possible function in germ tissue protection. Life Sciences, 67(25): 3023-3029.

Mercolini L, Addolorata Saracino M, Bugamelli F, Ferranti A, Malaguti M, Hrelia S, Raggi MA, 2008. HPLC-F analysis of melatonin and resveratrol isomers in wine using an SPE procedure. Journal of Separation Science, 31(6-7): 1007-1014.

Mercolini L, Mandrioli R, Raggi MA, 2012. Content of melatonin and other antioxidants in grape-related foodstuffs: measurement using a MEPS-HPLC-F method. Journal of Pineal Research, 53(1): 21-28. 
Millet B, Touitou Y, Poirier MF, Bourdel MC, Amado I, Hantouche EG, Olié JP, 1999. Obsessive-compulsive disorder: evaluation of clinical and biological circadian parameters during fluoxetine treatment. Psychopharmacology, 146(3): 268-274.

Mollaoglu H, Ozguner MF, 2005. Yaslanma surecinde melatoninin rolu. Suleyman Demirel Üniversitesi Tip Fakultesi Dergisi, 12: 52-56.

Ostrowska Z, Kos-Kudla B, Marek B, Kajdaniuk D, Staszewicz P, Szapska B, Strzelczyk J, 2002. The influence of pinealectomy and melatonin administration on the dynamic pattern of biochemical markers of bone metabolism in experimental osteoporosis in the rat. Neuroendocrinology Letters, 23(1): 104-110.

Ozcelik F, Erdem M, Bolu A, Gülsün M, 2013. Melatonin: Genel özellikleri ve psikiyatrik bozukluklardaki rolü. Psikiyatride Güncel Yaklaşımlar, 5(2): 179-203.

Paredes SD, Korkmaz A, Manchester LC, Tan DX, Reiter RJ, 2009. Phytomelatonin: a review. Journal of Experimental Botany, 60(1): 57-69.

Reiter RJ, 1991. Neuroendocrine effects of light. International Journal of Biometeorology, 35(3): 169-175.

Reiter RJ, 2002. Potential biological consequences of excessive light exposure: melatonin suppression, DNA damage, cancer and neurodegenerative diseases. Neuroendocrinology Letters, 23: 9-13.

Reiter RJ, Manchester LC, Tan DX, 2005. Melatonin in walnuts: influence on levels of melatonin and total antioxidant capacity of blood. Nutrition, 21(9): 920-924.

Reiter RJ, Tan DX, 2003. Melatonin: a novel protective agent against oxidative injury of the ischemic/reperfused heart. Cardiovascular Research, 58(1): 10-19.

Reiter RJ, Tan DX, Erren TC, Fuentes-Broto L, Paredes SD, 2009. Light-mediated perturbations of circadian timing and cancer risk: a mechanistic analysis. Integrative Cancer Therapies, 8(4): 354-360.

Sangsopha J, Johns NP, Johns J, Moongngarm A, 2020. Dietary sources of melatonin and benefits from production of high melatonin pasteurized milk. Journal of food science and technology, 1-12.

Sener G, Goren FO, Ulusoy NB, Ersoy Y, Arbak S, Dólger GA, 2005. Protective effect of melatonin and omeprazole against alendronat-induced gastric damage. Digestive Diseases and Dciences, 50(8): 15061512.

Stürtz M, Cerezo AB, Cantos-Villar E, Garcia-Parrilla MC, 2011. Determination of the melatonin content of different varieties of tomatoes (Lycopersicon esculentum) and strawberries (Fragaria ananassa). Food Chemistry, 127(3): 1329-1334.

Suzuki N, Somei M, Seki, A, Reiter RJ, Hattori A, 2008. Novel bromomelatonin derivatives as potentially effective drugs to treat bone diseases. Journal of Pineal Research, 45(3): 229-234.

Şener G, 2010. Karanlığın hormonu: Melatonin. Marmara Eczacılık Dergisi. 14: 112-120.

Tan DX, Manchester LC, Reiter RJ, Qi W, Kim SJ, El-Sokkary GH, 1998. Ischemia/reperfusion-induced arrhythmias in the isolated rat heart: prevention by melatonin. Journal of Pineal Research, 25(3): 184-191.

Yildiz M, Akdemir O, 2009. Assessment of the effects of physiological release of melatonin on arterial distensibility and blood pressure. Cardiology in the Young, 19(2): 198-203. 